\title{
Re-Examining Religious Insecurity in the Africa State: The Menace and Security Challenges of Boko Haram in Nigeria
}

\author{
Emmanuel M. Ome, Ani Casimir \\ Department of Philosophy, University of Nigeria, Nsukka, Nigeria \\ Email: Nsukka.dromemma@yahoo.com, cepperngo@yahoo.com \\ Received 26 February 2015; accepted 16 March 2015; published 18 March 2015 \\ Copyright @ 2015 by authors and Scientific Research Publishing Inc. \\ This work is licensed under the Creative Commons Attribution International License (CC BY). \\ http://creativecommons.org/licenses/by/4.0/

(c) (i) Open Access

\begin{abstract}
This paper focuses on the emerging threats posed by the Boko Haram sect. It probes into its historical evolutions, highlights its causes and effects, and analyses its radicalisation into a violent extremist movement. It contends that the sect's growing capacity to mount both "low-scale" and "lone" attacks demands that the Nigerian security forces and perhaps the international community begin to pay more attention to the emerging security challenge posed by this movement, in order to abort its possible transnational terrorist potential.
\end{abstract}

\section{Keywords}

Africa, Religious Insecurity, Boko Haram, Terrorism, Nigeria

\section{Introduction}

In Africa, issues of insecurity are serious as challenges to the stability and continuity of the Africa state. The insecurity in Nigerian threatens lives and property on daily basis. It is a good example of an unsecured African state, shaken to its knees by the scourge of religious violence and fundamental disruptions. Unless the threat of religious insecurity and its violence is well managed, it will be problematic for the new Africa to emerge under the shadows of religious extremism and violent disruptions of the stability of the state. The questions of security and insecurity in Nigeria have remained topical since independence. The inauguration of democratic government in Nigeria on May 29, 1999 has further brought to the fore the question of security of the nation state and the democratic order itself. No one can in all honesty say that he is free from risk or danger, from the ordinary citizen to the top echelon of society. Today, we are witnessing particularly the disturbing and damaging effects of the Boko Haram sect. The manner this menace is developing is now a matter of intense national and global 
concern, and it is threatening to trigger even wider conflicts in the polity. With all the human, technical and material resources at its disposal, government appears incapable of preventing spectacular and devastating attacks on security agents and the public. There is no doubt that the security situation in Nigeria today is precarious. This paper documents and analyses the Boko Haram uprising, as well as its causes and effects and the challenges it poses to the security of the Nigerian state. Finally, the paper proposes strategic measures that would be useful for addressing the menace of Boko Haram sect.

\section{Historical Development and Activities of the Boko Haram Sect}

Boko Haram is a controversial Nigerian militant Islamist group that seeks the imposition of Shariah law in the northern states of Nigeria. The term "Boko Haram” comes from the Hausa word boko meaning "Animist, western or otherwise non-Islamic education” and the Arabic word haram figuratively meaning "sin” (literally, "forbidden”) (Ogbonnaya, 2011: p. 12). Boko Haram opposes not only Western education, but Western culture and modern science as well. The group was founded in 2002 in Maiduguri by Ustaz Mohammed Yusuf. In 2004 it moved to Kanamma, Yobe State, where it set up a base called “Afghanistan”, used to attack nearby police outposts, killing police officers. Boko Haram conducted its operations more or less peacefully during the first seven years of its existence, withdrawing from society into remote north-eastern areas. The government repeatedly ignored warnings about the increasingly militant character of the organization (Cook, 2006). In 2009 police began an investigation into the group code-named “Operation Flush”. On 26 July, security forces arrested nine Boko Haram members and confiscated weapons and bomb-making equipment. Either this, or a clash with police during a funeral procession, led to revenge attacks on police and widespread rioting. A Joint Military Task Force operation was launched in response, and by 30 July more than 700 people had been killed, mostly Boko Haram members, and police stations, prisons, government offices, schools and churches had been destroyed. Yusuf was arrested, and died in custody "while trying to escape”. He was succeeded as leader by Abubakar Shekau, formerly his second-in-command. A classified cable sent from the US Embassy in Abuja in November 2009, available on WikiLeaks, is illuminating:

"[Borno political and religious leaders]... asserted that the state and federal government responded appropriately and, apart from the opposition party, overwhelmingly supported Yusuf's death without misgivings over the extrajudicial killing. Security remained a concern in Borno, with residents expressing concern about importation of arms and exchanges of religious messages across porous international borders. The government has proposed a preaching board which will certify Muslim preachers, but it has not yet been inaugurated. While most contacts described Borno as a 'State of Peace' and did not expect additional attacks, the Northeast remained vulnerable to violence and extremist attacks due to lack of employment opportunities for youth, exasperated by ethnic and religious tensions.” Government officials were aware of arms shipments coming into Borno; there were reports that Yusuf's deputy had survived, and audio tapes were believed to be in circulation in which Boko Haram threatened future attacks. However, many observers did not anticipate imminent bloodshed. Security in Borno was downgraded. Borno government official Alhaji Boguma believed that the state deserved praise from the international community for ending the conflict in such a short time, and that the "wave of fundamentalism has been crushed.” In September 2010, having regrouped under their new leader, Boko Haram broke 105 of its members out of prison in Maiduguri along with over 600 other prisoners and went on to launch attacks in several areas of northern Nigeria. As had been the case decades earlier in the wake of the 1980 Kano riots, the government's reliance on a purely military strategy, once again executing the leader of a militant group, would have unintended consequences (Ewi, 2013).

Under Shekau's leadership, the group continuously improved its operational capabilities. After launching a string of IED attacks against soft targets, and its first vehicle-borne IED attack in June 2011, killing 6 at the Abuja police HQ, in August Boko Haram bombed the UN HQ in Abuja, the first time they had struck a Western target. A spokesman claiming responsibility for the attack, in which $11 \mathrm{UN}$ staff members died as well as 12 others with more than 100 injured, warned of future planned attacks on US and Nigerian government interests. Speaking soon after the US embassy's announcement of the arrival in the country of the FBI, he went on to announce Boko Haram's terms for negotiation: the release of all imprisoned members. The increased sophistication of the group led observers to speculate that Boko Haram was affiliated with AQIM, which was known to be active in Niger (Nigerian Defence Headquarters Press Release, 2014). Boko Haram have maintained a steady rate of attacks since 2011, striking a wide range of targets, multiple times per week. They have attacked politi- 
cians, religious leaders, security forces and civilian targets. The tactic of suicide bombing, used in the two attacks in the capital on the police and UN HQs, was new to Nigeria, and alien to its mercenary culture. In Africa as a whole, it had only been used by al-Shabab in Somalia and, to a lesser extent, AQIM. Since early 2013 Boko Haram have increasingly operated in Northern Cameroon, and have been involved in skirmishes along the borders of Chad and Niger. They have been linked to a number of kidnappings, often reportedly in association with the splinter group Ansaru, drawing them a higher level of international attention. Beginning in August 2014, they changed their "hit-and-run" tactics, instead occupying swathes of territory in northeast Nigeria from which the increasingly beleaguered Nigerian military were unable or unwilling to expel them (Nigerian Defence Headquarters Press Release, 2014).

\section{Causes and Effects of Boko Haram}

Boko Haram made its presence known in 2004, in Yobe State. And by 2011, it made its presence known to the global community by bombing the United Nations headquarters in Abuja. Especially in the last two years, it has willfully attacked hundreds of buildings and killed many innocent Nigerians. Until recently, very few-including the Nigerian security and intelligence agencies - knew very little about the group's origin and philosophy, its raison d'être, and its goals and endgame. Eight years after it came into existence, and in spite of the calamity the group has caused, the government seems not to know how to clip the group's wings.

According to Kashim Shettima, Governor of Borno State, widespread poverty, illiteracy, high rate of youth unemployment and youth anger provided a fertile ground for the Boko Haram insurgency. From the 1980 Maitatsine uprising to the 2009 Boko Haram uprising, Nigeria was bedevilled by ethno-religious conflicts with devastating human and material losses. But the Boko Haram uprising of July 2009 was significant in that it not only set a precedent, but also reinforced the attempts by Islamic conservative elements at imposing a variant of Islamic religious ideology on a secular state. Whereas the religious sensitivity of Nigerians provided fertile ground for the breeding of the Boko Haram sect, the sect's blossoming was also aided by the prevailing economic dislocation in Nigerian society, the advent of party politics (and the associated desperation of politicians for political power), and the ambivalence of some vocal Islamic leaders, who, though they did not actively embark on insurrection, either did nothing to stop it from fomenting, or only feebly condemned it. These internal factors coupled with growing Islamic fundamentalism around the world make a highly volatile Nigerian society prone to violence, as evidenced by the Boko Haram uprising.

Boko Haram has domestic and global implications on Nigeria. For instance, Boko Haram's successes make the security agencies look inept. As a result, there is a growing perception that the police and their allied organizations are weak, corrupt, and poorly trained. Above all, it paints these units as cowards who are unable to arrest, dismantle, and bring to justice a ragtag group running wild at the edge of the Sahara Desert. This perception, whether true or not, will most likely have a negative impact on the trust and confidence level of those who see the police as their defenders. Again, the daily trouncing of the security and intelligence services is likely to have a demoralizing impact. Low-ranking members may begin to doubt the ability of their leaders to make the right calls; and the senior ranks too may begin to doubt the vision and the ability of their superiors. These and other factors are likely to have a negative impact on the cohesiveness of the security and intelligence agencies. In addition, civilians and non-civilians may begin to doubt the leadership capability of the government.

And finally, the incessant bombings may lead to equivalent retaliation: Boko Haram (a Northern group) may provoke one or two other groups or groups of individuals in the South to avenge the killing of their brethren - or the bombing of their churches. On the other hand, if Boko Haram were to bomb Lagos, such an act would most likely provoke equivalent retaliation and mass exodus of Nigerians of northern extraction from Lagos and adjacent cities/states. And if the bombing and counter-bombings are prolonged, the country may witness pre-1967 conditions. In the end, therefore, one of the unintended consequences of the Boko Haram's rampage may be the weakening of the state or the breakup of the country. Prolonged anarchy or the breakup of the country will definitely have a dire consequence on the African continent and beyond. Should this continue unabated for several more months, Foreign Direct Investments in Nigeria are likely to decrease. And this has wider implications for a government that has promised its citizens transformation!

\section{Catalogue of Boko Haram's Attacks}

Boko Haram, a Muslim rebel movement based in northeastern Nigeria, is a frequent topic as far as security 
situation in Nigeria is concerned, and has been a subject of increasing scrutiny by journalists and policymakers following the June 16 bombing at the police headquarters in Abuja. What follows is a list of Boko Haram's attacks from July 2009 to the present.

In the state of Yobe, fighters reportedly "used fuel-laden motorcycles" and "bows with poison arrows" to attack a police station. On 30 July 2009, allegations were made that Yusuf himself was killed by Nigerian security forces after being taken into custody. In January 2010, the group struck again in the Nigerian state of Borno, killing four people in Dala Alemderi ward in Maiduguri metropolis. On September 7, 2010, Boko Haram freed over 700 inmates from a prison in Bauchi State. In December 2010, Boko Haram was blamed for a market bombing, following which 92 of its members were arrested by police. On Friday January 28, 2011, a gubernatorial candidate was assassinated, along with his brother and four police officers. On March 29, 2011, police "thwarted a plot to bomb an (ANPP) election rally" in Maiduguri, Borno State. On April 1, 2011, (the day before the original date of Nigeria's legislative elections), suspected Boko Haram members attacked a police station in Bauchi. On April 9, 2011, a polling center in Maiduguri was bombed. On April 15, 2011, the Maiduguri office of the Independent National Electoral Commission was bombed, and several people were shot in a separate incident on the same day. On April 20, 2011, Boko Haram killed a Muslim cleric and ambushed several police officers in Maiduguri. Boko Haram was blamed for a series of bombings in northern Nigeria on May 29, 2011 that left 15 dead. On June 17, 2011, the group claimed responsibility for a bombing attack on the police force headquarters in Abuja that occurred the previous day. Officials believed that the attack was the first suicide bombing in Nigeria's history and that it specifically targeted formal Police Inspector-General Hafiz Ringim.

On August 26, 2011, Boko Haram claims responsibility for a suicide bombing against the UN compound in Abuja, killing at least 25 people. On November 4, 2011, a series of attacks on police targets and churches in the northeastern city of Damaturu claimed by the sect kills at least 150 people. On December 22-23, 2011, attacks in the cities of Damaturu, Potiskum and Maiduguri claimed by the group along with a heavy military crackdown leave up to 100 people dead. On December 25, a wave of attacks claimed by the group targeting churches during Christmas services and police leave 49 people dead.

In 2012, January 20, at least 185 people are killed in the northern city of Kano following coordinated bombings and gun battles, claimed by Boko Haram. On February 15, 2012, Boko Haram claims a raid on a prison in central Nigeria in which 119 inmates are set free. On April 8, 2012, an Easter bomb attack on a church in the northern city of Kaduna claims at least 41 lives. On June 17, 2012, Boko Haram claims suicide attacks at three churches at Kaduna and Zaria, sparking reprisal violence by Christian mobs who burn mosques and target their Muslim neighbours. More than 100 are killed over a week.

In 2013, February 19, a French family of seven is kidnapped in Cameroon and taken to Nigeria. Boko Haram claims responsibility. The family is freed on April 20. On March 18, 2013, a suicide attack at a bus station in second largest city Kano kills 41. On May 7, 2013, Boko Haram launches coordinated attacks in the northeastern town of Bama, killing 55 people and freeing 105 inmates. On May 15, 2013, Nigerian troops begin an offensive against Boko Haram in the states of Borno, Yobe and Adamawa, where a state of emergency is declared in order to retake areas which have fallen into the hands of the insurgents. On July 6, 2013, gunmen believed to be from Boko Haram attack a secondary school in the northeastern state of Yobe, killing 42 people, many of whom were students. Nigerian authorities frequently exaggerate their efforts in arresting or cracking down on Boko Haram, which has carried out scores of bombings and shootings. Violence linked to Boko Haram's insurgency in northern and central Nigeria, including killings by security forces, is believed to have left more than 2800 people dead since 2009 (Nossiter, 2009).

\section{Boko Haram and the Security Situation in Nigeria}

The Boko Haram question has constituted a serious security threat and challenge to the Nigerian polity. The group has been attacking the police, military and civilian targets with utmost effrontery, vendetta and destruction. The Madalla Christmas attack, the serial bombing in Kano and the Bauchi attack are very recent instances. The group that had been pervasive in the North East migrated to the North West amid the state of emergency in some local government areas in Borno and Yobe states. The Madalla attack at the St. Theresa's Catholic Church drew local and global outrage. The killings were mindless, vicious and callous attacks on innocent citizens on the $\mathrm{Yu}-$ letide. The Madalla attack was dastardly and condemnable. The most recent attacks in Kano suggest the migratory nature of the group, the seeming helplessness of security agencies and the coordinated nature of the attacks. 
The attack on police formations and immigration office in Kano strongly suggests deliberate plans to weaken the capacity of these security agencies to respond to the Boko Haram challenge. It is also noteworthy that a Channels Television correspondent/cameraman was killed in Kano (Nossiter, 2009).

It points to the risk the Fammedia officers are exposed to, and the need for practitioners to review their personal safety measures. It is sad and vexatious that the leadership is pursuing politics amidst recurring killings and destruction of property by the Boko Haram sect. Critics had asked the Federal Government to pursue a full scale military action against the sect. I am not certain that a full blown military option will deal with the Boko Haram question. The group has been using guerilla tactics; underground formations, cell based groups, unknown or faceless membership and sudden attacks on perceived targets (Nossiter, 2009).

It will be difficult to pursue a comprehensive military action against this group that relies on guerilla strategy. The President should begin with a review of its topmost security structure and this might involve the replacement of security chiefs. Secondly, I doubt if there has been a serious scientific study on Boko Haram to delineate its origin, purpose, tactics and operational patterns. The state should commission a sociological study and reconcile same with detailed intelligence inquiry.

The state will not possibly deal with the Boko Haram group without a deep knowledge of what it is and how it is patterned. The sociological dimension will identify the recruiting sources, the socio economic status of recruitees. It will investigate why recruits are willing to join the group despite the risk? Why recruits are willing to commit suicide bombings? What social factors pre dispose the members to joining the group? What possible links exist among Boko Haram, Yandaba and Almajiris in the North? How did Yandaba and Almajiri emerge? Are there political manipulations of the Boko Haram sect? Why is the group pre disposed to political manipulation? Who constitutes its intellectual wing? Who are its financiers? What are the external organizations linked to Boko Haram? These questions will assist to deconstruct the group and provide clearer insights on how to confront the challenge posed by it? The security challenge has been viewed as a component of the national question.

The Boko Haram release that Southerners and Christians should leave the North raises political, ethnic and religious question. These issues make the security question intricate and thus constitute a serious threat to the survival of the federation. The state cannot deny a national dialogue or conference for too long to resolve these issues; otherwise the survival of the polity will be compromised.

The constitution amendment process is inadequate; a more politically inclusive approach is required to mediate the contradictions and structural distortions in the federation. Critics point at the interface of human welfare and security in Nigeria. The low human conditions and poor capacity of the state for social provisioning is perceived as predisposing the populace to violence and exacerbating the security challenge. The state had emphasized hardware security to the neglect of human or social security.

The human security challenge requires creative governing elite to resolve. It involves economic democratization, political pluralism, social provisioning, a capable state, benevolent and nationalist governing elite. It is doubtful that emphasis on hardware security will foster social stability; the political elite should reconcile socio political considerations with military requisites. These are minimum conditions for socio-political stability in Nigeria.

Boko Haram is considered to be a major potential terrorist threat affecting Nigeria and other countries, and US officials believe it is potentially allied with Al Qaeda. The US House of Representatives Subcommittee on Counterterrorism and Intelligence urged the Obama Administration and US intelligence community in November 2011 to focus on Boko Haram as a potential threat to United States territory (US House of Representatives, 2011).

Nigeria's National Security Adviser, General Owoye Andrew Azazi, has been working with other African governments, European and Middle Eastern governments, and the US government to build cooperation against Boko Haram. He met in 2010 with then-CIA Director Leon Panetta, and in 2011 with AFRICOM Commander General Ham, and other US officials, and was in the United States when the congressional panel was preparing its report on Boko Haram. He participated in a CIA conference at about the same time (CIA, 2011). After the Christmas 2011 bombings carried out by Boko Haram, President Barack Obama's office issued a statement that confirmed that the US and Nigeria were cooperating at a senior level against the terrorist group.

\section{The Way Forward}

The Nigerian government is desperately trying to get the United States to list Boko Haram as a terrorist organi- 
zation, with an eye on extensive assistance in funding, training, intelligence and logistics which is bound to be intrusive and complicating. All these make the need to explore some practical steps towards a comprehensive resolution of this stand-off imperative. One of these practical steps should involve exploring the value of mutual acceptance of a three months moratorium on all attacks and arrests. In these three months, avenues should be explored to put arrested Boko Haram suspects through the judicial process, and where it serves the law and public interest and security, they may be released from detention. The insurgency leaders should also demonstrate their control over their people by ceasing attacks, and perhaps, in this manner, they may expose criminals widely suspected to be killing Nigerians and attacking churches and banks and other government institutions.

Above all, it may help to convince the nation that the insurgency has both a capacity to inflict violence, as well as discipline and political maturity, and is not just a ragtag army of people who know how to make and explode bombs. A three month moratorium on hostilities and arrest should be used by both the government and Boko Haram leadership to intensely explore options to their current strategies. The challenge, of course, is to find who will broker this ceasefire agreement. Respected Ulama and other leaders should get involved in mediating between the two, with firm assurances that their safety and integrity will not be compromised. There must be people respected and trusted by Boko Haram leaders, and acceptable to governments, who also have the courage to step forward. This is the time for leadership and sacrifice.

The period should be used to explore genuine avenues for resolving the core grievances of the insurgency, and no options should be excluded. By the end of the moratorium, a formal and structured platform should emerge which may allow an all-inclusive dialogue and a roadmap towards a comprehensive resolution. The proposal for a moratorium on hostilities, arrests and trials should be given serious consideration by those genuinely involved in the search for solutions. The north is paying a disproportionate price for this insurgency, which is a national problem. Where the national leadership fails to act, or has no ideas, northern leaders should step up their involvement for the search for peace.

\section{Conclusion}

Security is the responsibility of every individual and not the exclusive responsibility of government. There will be some Nigerians who will scoff at the idea of the ceasefire and dialogue with Boko Haram insurgents, but they should be reminded that it was dialogue and massive concessions initiated by a President from the north that brought the delicate and expensive resolution to the Niger Delta insurgency. There may be some in government who will feel that government is capitulating. They should be reminded that the government is actually losing this war, and it shows no capacity to win it in the long run, going by its present disposition. There may be some in the Boko Haram leadership who will insist on fighting on. But they should know that fighting alone, without some objectives which are achievable, is a wasteful exercise. The nation has taken note that Boko Haram has a grievance, and a capacity to force attention to it. It is time to consolidate on this, and not fritter it away in a war that is fast taking its toll on it. Above all, it is time for all Nigerians, particularly those respected by the people as men and women with unimpeachable integrity, leaders of opinion and the ulama to stand between the government and the Boko Haram insurgency, and broker a ceasefire. In confirmation of the dangerous dimension which Boko Haram represents as an emerging terrorist organization with global dimensions, let us take a glimpse of what David Cook (2011: p. 3) observed below, in terms of capturing power in Nigeria and foisting Islamic rule.

Boko Haram has been able to project power over the northeastern section of Nigeria, where the police and army have effectively lost control. They have not, however, succeeded in going beyond their ability to impose terror upon the capital of Borno State, Maiduguri, into actually attempting to assume power. Yet Boko Haram has definitely been able to tap into discontent among northern Muslims, who have not been satisfied with the imposition of Shari'a during the years since 2000 (people expected that the draconian punishments would curtail corruption and crime; Boko Haram offers a more direct and violent solution). There are reports that even northern Muslim soldiers sent to infiltrate the group have joined it. Opposition from major Muslim religious figures in the north suggests that Boko Haram has local opposition that it needs to silence to maintain its control. Boko Haram's transition into the use of suicide attacks suggests that the group might have connections to other major Salafi-jihadi organizations. The release of a martyrdom video in September 2011, a media event not associated with regional radical Islamic groups, suggests connections with either AQIM or al-Shabab, both of whom use this methodology. It is interesting, however, that no major ideological statement can be associated with Boko 
Haram that states the group's objectives or program. The group, as its name implies, is only defined by what it stands against rather than what it stands for. It is interesting, however, that its targets have been very specific, and that in contradistinction to other Muslim groups Boko Haram has only rarely attacked Christians. The vast majority of its targets have been either obviously official or in line with a purificationist agenda toward Muslims.

\section{References}

Akpor, A. (2013). Security Report on the Security Challenges in Nigeria (a Correspondent for NTA from Abuja).

CIA Report (2011). Hosts General Azazi at Reagan Library Symposium. Atlantisphere.

Cook, D. (2011). The Rise of Boko Haram in Nigeria. Combating Terrorism Centre. http://en.wikipedia.org/wiki/Boko_Haram

Ewi, M. (2013). Why Nigeria Needs a Criminal Tribunal and Not Amnesty for Boko Haram. Institute for Security Studies. www.issafrica.org/.../why-nigeria-needs-a-criminal-tribunal-and-not-amn

Mark, M. (2012). Scores Dead in Northern Nigeria as Islamist Militants Terrorise the Country. The Observer.

Nigerian Defence Headquarters Press Release (2014). New Plot against Operations of Nigerian Military-Defence. www.reubenabati.com.ng

Nossiter, A. (2009). Scores Die as Fighters Battle Nigerian Police. The New York Times.

Ogbonnaya, O. (2011). Boko Haram Is Battle for 2015, Says Chukwumerije. The Nation.

US House of Representatives, Committee on Homeland Security (2011). Boko Haram: Emerging Threat to the U.S. Homeland. Report of the Subcommittee on Counterterrorism and Counterintelligence. 